\title{
Demographic Factors and Job Satisfaction Among Teachers in Lower Secondary Schools in Albania
}

\author{
Enida Kume
}

\section{ABSTRACT}

\begin{abstract}
A sample of 198 Albanian teachers in lower secondary schools, randomly selected, was used for investigates the relationship between job satisfaction and their demographic factors. The objective of this study was therefore to examine the influence of demographic factors on job satisfaction of teachers in lower secondary, public and private, schools. Descriptive statistics, analyze of variances (ANOVA) and logistic regression analyze were used to analyze the data. The overall finding was that: (i) between job satisfaction among the teachers in lower secondary schools in Albania and their demographic characteristics a significant relationship was identified, (ii) Female teachers declare more satisfied as male teachers $(3.97 \pm 0.3$ vs $2.87 \pm 0.41)$. The teachers`age and work experiences are positively correlated with job satisfaction $(p<0.01)$. The teachers $31-40$ years old have about 2.207 times higher chance to be satisfied than the teachers $20-30(p<0.01)$ years old and the teachers who have a long teaching period, have about 2.6 times more opportunities to be satisfied compared to the teacher who have work experience $<5$ years $(p<0.01)$. Civil status of teachers is a demographic determinant with a less influence on job satisfaction. The social-economic factors, property status of school (public or private) and residential area where the school is located (urban or peri-urban/rural), both have no significant influence on job satisfaction among the Albanian teachers in lower secondary schools.
\end{abstract}

Keywords: Job satisfaction, demographic and social-economic factors, teachers in lower secondary schools
Published Online: December 20, 2020

ISSN: $2684-446 \mathrm{X}$

DOI : $10.24018 /$ ejedu.2020.1.1.8

Enida Kume

University “Aleksandër Moisiu” Durrës Albania

(enidak@hotmail.it)

\section{INTRODUCTION}

The study of the relationship between teachers' job satisfaction and their demographic characteristics is important for the interventions that can be made in public policy and in the different administration aspects in schools that offer studies in the lower secondary education cycle. [8] states that "Job satisfaction is a positive emotional state or manifestation of satisfaction caused by the employee's appreciation for his work or work experiences". [12] concluded that: "Alongside with job characteristics and organizational characteristics, the personal characteristics (demographic variables) are considered as primary determining factors to job satisfaction". A considerable amount of research on the role of gender, age, professional characteristics, teaching experience, civil and family status of teacher, together with factors related to the propriety status of schools (public or private) and zone (urban or rural areas) was conducted in different countries.

According to [27] "Studies of job satisfaction and teacher retention usually use teacher personal characteristics such as age and gender, teacher professional characteristics such as years of teaching experience, degree level and type.." In the same paper Toropova A. et al. theksojne se "Generally, research on teacher gender and job satisfaction is characterised by a large degree of inconsistency.." [22]_found that "..teachers' age being weakly correlated with job satisfaction, while gender had no effect". Crossman \& Harris, 2006 in their paper publish "English teachers' job satisfaction revealed no significant gender differences" while in another paper [20] women were found to be more satisfied with the teaching job. In case of teachers in Public Primary Schools, Kenya, [6] have declare “...there was no significant difference between the levels of job satisfaction between male and female teachers. On the other hand, it was found that job satisfaction was positively correlated with the 'age of respondent' $(\mathrm{r}=0.092 ; \mathrm{p}<0.01)$ and 'experience in teaching' $(\mathrm{r}=0.081 ; \mathrm{p}<0.05)$ ". A considerable number of authors point out that "..the effects of teacher gender are rather mixed; one of the reasons for this may be the interaction with other professional and personal factors, as well as working environment aspects specific to a particular grade, domain level and school characteristics" [1], [13], [28].

The studies of relationship between job satisfaction among Albanian teachers in pre university education cycles and their demographic characteristics, are limited. Based on a survey of 1000 Albanian middle school teachers, [21] found that: "...some of the demographic and school characteristics (age, tenure, teacher level of education and school size) were negligibly related to overall teacher's job satisfaction". 
[4] communicates “...job satisfaction among teachers in secondary high school in Albania is influenced by their demographics characteristics". He has identified a significant difference $(p<0.05)$ between male and female. Level of job satisfaction increases with teachers` age. The age group over 49 is more satisfied than the age groups 35-49 and 25-34. Work experience has a positive effect. Older teachers in education are more satisfied than teachers with fewer years of service in education.

\section{A. Propose of the study}

The main purpose of this study is to identify the relationship between overall job satisfaction and demographic characteristics of Albanian teachers in lower secondary schools Personal characteristics taken into this study are gender, age, education level and teaching experience. Another variable in the study is classroom size, number of pupils at classroom, related to school characteristics.

\section{B. Objective of the study}

Determine whether demographic factors hand any influence on job satisfaction among teachers in lower secondary schools in Albania

\section{C.Hypothesis}

$\mathrm{H}_{01}$ : There is a significant relationship between job satisfaction among the teachers in lower secondary schools in Albania and their demographic characteristics

$\mathrm{H}_{02}$ : Property status of school (public or private) has no significant influence on job satisfaction among the Albanian teachers in lower secondary schools.

$\mathrm{H}_{03}$ : Residential area where the school is located (urban or peri-urban/rural) has no significant influence on job satisfaction among the Albanian teachers in lower secondary schools.

\section{Research Methods}

The data analyses were performed by using of descriptive statistics, analyze of variances (ANOVA), and regression analysis. Based on the logistic regression analysis it was estimated odds ratios that the teachers is satisfied, corresponding of different levels for each demographic factor, and property status of schools and residential area where the school is locate that are considered as socioeconomics factors. The binary logistic regression model used in this study is follow:

$$
Y_{i j n}=\beta_{0 j}+\beta_{1 j} X_{1 i j}+\beta_{2 j} X_{2 i j}+\varepsilon_{i j n}
$$

where:

$\mathrm{Y}$ - dependent variable, whose value is one of two states: Teacher is satisfied (1), Teacher is not satisfied (0).

$\mathrm{X}_{1 \mathrm{ij}}$ - independent variables- demographic characteristics of teachers: gender, age, work experience, civil status

$\mathrm{X}_{2 \mathrm{ij}}$ - independent variables: socio-economic factorsproperty status of schools and residential area where the school is located.

The values of the dependent variable, which reflects the job satisfaction of teachers, were calculated according to the rule:
Teachers for whom the average value of total job satisfaction is $\leq 2.9$, are classified in the group of dissatisfied teachers, $\mathrm{y}=0$

Teachers for whom the average value of total job satisfaction is $\geq 3.0$, are classified in the group of teachers satisfied with the job, $\mathrm{y}=1$.

\section{E. Data}

The data for this study derive from the answers received from 198 teachers in lower secondary schools. These schools are distributed in the central region of Albania, where live about $69 \%$ of the Albanian population. The questionnaire used was drafted after consultation with the literature [4], [5], 15], [18], [25], [26], [31]. There are 22 questions in the questionnaire (6 questions that correspond to factors of motivation and 16 hygiene factors). The answers to the questions generate the values of a five-point Likert scale, with $1=$ strongly disagree; $2=$ disagree; $3=$ between agreeing and disagree; $4=$ agree; and $5=$ strongly agree.

\section{F. Characteristics of sample}

About $18 \%$ of teachers interviewed are male. In Albania, male teachers in lower secondary schools make up about $16 \%$. About $12.6 \%$ of the teachers working in private schools. Nationwide, private lower secondary schools account for about $10.2 \%$ of the total number of these schools. The sample is also representative in terms of the distribution of schools in urban and peri-urban / rural areas $(71.8 \%$ / $28.8 \%$ vs $67.3 \% / 32.7 \%$; $<0.05$ ) (Table .1)

\begin{tabular}{l} 
TABLE 1 CHARACTERISTICS OF SAMPLES \\
\begin{tabular}{|l|c|c|}
\hline \multicolumn{2}{|c|}{ Number } & $\%$ \\
\hline Gender & & \\
\hline Female & 162 & 81.8 \\
\hline Mal & 36 & 18.2 \\
\hline Age & & \\
\hline $20-30$ year old & 49 & 24.7 \\
\hline $31-40$ year old & 80 & 40.4 \\
\hline$>40$ year old & 69 & 34.8 \\
\hline Work experience & & \\
\hline$<5$ years & 55 & 27.8 \\
\hline $5-10$ years & 67 & 33.8 \\
\hline$>10$ years & 76 & 38.4 \\
\hline Civil status & & \\
\hline Single & 31 & 15.7 \\
\hline Married & 126 & 63.6 \\
\hline Divorced & 29 & 14.6 \\
\hline Widow/ wifeless & 12 & 6.1 \\
\hline Property status & & \\
\hline Private school & 25 & 12.6 \\
\hline Public school & 173 & 87.4 \\
\hline Areas & 141 & 71.8 \\
\hline Urban & 57 & 28.8 \\
\hline Periurban/rural & & \\
\hline
\end{tabular} \\
\hline
\end{tabular}

II. RESULTS - DESCRIPTIVE ANALYZE

In Table. 2 are shown the results of descriptive analysis and ANOVA-One way. 
TABLE 2 DESCRIPTIVE ANALYSIS AND ONE-WAY ANOVA RESULTS OF DEMOGRAPHIC CHARACTERISTICS AND SOCIO-ECONOMIC FACTORS ON JOB SATISFACTION

\begin{tabular}{|c|c|c|c|c|c|c|c|}
\hline \multicolumn{2}{|r|}{ Items } & Number & Mean & Std. Dev. & $\mathrm{F}$ & Sign. & Difference \\
\hline \multirow{2}{*}{ Gender } & Female & 162 & 3.97 & 0.30 & \multirow{2}{*}{$\begin{array}{l}\text { t-value } \\
1.91 *\end{array}$} & \multirow{2}{*}{0.05} & \multirow{2}{*}{ Significant difference $(\mathrm{p}<.05)$} \\
\hline & Mal & 36 & 2.87 & 0.49 & & & \\
\hline \multirow{3}{*}{ Age } & 20-30 years old & 49 & 2.98 & 0.49 & \multirow{3}{*}{$4.21^{*}$} & \multirow{3}{*}{0.04} & \multirow{3}{*}{$\begin{array}{l}\text { Teacher } 31-40 \text { years old and } 20-30 \text { years } \\
\text { are statistically significantly }(\mathrm{p}<.05) \\
\text { different. Teacher }>40 \text { years old and } 20- \\
30 \text { years old are statistically significantly } \\
\qquad(\mathrm{p}<.05) \text { different. }\end{array}$} \\
\hline & $31-40$ years old & 80 & 4.02 & 0.41 & & & \\
\hline & $>40$ years old & 69 & 3.76 & 0.51 & & & \\
\hline \multirow{3}{*}{$\begin{array}{c}\text { Work } \\
\text { experience }\end{array}$} & $<5$ years & 55 & 2.51 & 0.52 & \multirow{3}{*}{$6.92 * *$} & \multirow{3}{*}{0.01} & \multirow{3}{*}{$\begin{array}{c}\text { Teacher with }<5 \text { years and } 5-10 \text { years } \\
\text { experience are statistically significantly } \\
(\mathrm{p}<.01) \text { different. Teacher }>10 \text { years old } \\
\text { and }<5 \text { years experiences are statistically } \\
\text { significantly }(\mathrm{p}<.01) \text { different. }\end{array}$} \\
\hline & $5-10$ years & 67 & 4.21 & 0.39 & & & \\
\hline & $>10$ years & 76 & 3.96 & 0.46 & & & \\
\hline \multirow{4}{*}{ Civil status } & Single & 31 & 3.24 & 0.49 & \multirow{4}{*}{$3.07 *$} & \multirow{4}{*}{0.058} & \multirow{4}{*}{$\begin{array}{l}\text { Teacher widow and single are } \\
\text { statistically significantly }(\mathrm{p}<.05) \\
\text { different. }\end{array}$} \\
\hline & Married & 126 & 3.89 & 0.51 & & & \\
\hline & Divorced & 29 & 3.72 & 0.39 & & & \\
\hline & Widow & 12 & 4.02 & 0.32 & & & \\
\hline \multirow{2}{*}{$\begin{array}{l}\text { Property } \\
\text { status }\end{array}$} & Private & 25 & 3.43 & 0.51 & \multirow{2}{*}{$1.12^{\mathrm{NS}}$} & \multirow{2}{*}{0.164} & \multirow{2}{*}{$\begin{array}{l}\text { No significant difference among the } \\
\text { groups }(p>.05)\end{array}$} \\
\hline & Public & 173 & 3.38 & 0.44 & & & \\
\hline \multirow{2}{*}{ Areas } & Urban & 141 & 3.57 & 0.50 & \multirow{2}{*}{$1.07^{\mathrm{NS}}$} & \multirow{2}{*}{0.172} & \multirow{2}{*}{$\begin{array}{l}\text { No significant difference among the } \\
\text { groups }(p>05)\end{array}$} \\
\hline & Periurban/rural & 57 & 3.12 & 0.42 & & & \\
\hline \multicolumn{2}{|c|}{ Overall job satisfaction } & 198 & \multicolumn{5}{|c|}{$3.41 \pm 0.47$} \\
\hline
\end{tabular}

In Table 3 are shown the results of logistic regression

TABLE 3 RESULTS OF LOGISTIC REGRESSION

\begin{tabular}{|c|c|c|}
\hline \multirow[t]{2}{*}{ Items } & \multicolumn{2}{|c|}{$\begin{array}{c}\text { Dependent variable: } \\
\text { Job satisfaction } \\
\text { Satisfied (1), Not satisfied (0) }\end{array}$} \\
\hline & $\beta$ & odds ratios \\
\hline \multicolumn{3}{|l|}{$\begin{array}{l}\text { Gender } \\
\text { Reference: Mal }\end{array}$} \\
\hline Female & $0.579^{*}$ & 1.784 \\
\hline \multicolumn{3}{|l|}{$\begin{array}{l}\text { Age } \\
\text { Referenca: } 20-30 \text { years old }\end{array}$} \\
\hline $31-40$ years old & $0.792^{*}$ & 2.207 \\
\hline$>40$ years old & $0.684^{*}$ & 1.983 \\
\hline \multicolumn{3}{|l|}{$\begin{array}{l}\text { Work experience } \\
\text { Reference: }<5 \text { years }\end{array}$} \\
\hline $5-10$ years & $0.964^{* *}$ & 2.624 \\
\hline$>10$ years & $0.925^{* *}$ & 2.521 \\
\hline \multicolumn{3}{|l|}{$\begin{array}{l}\text { Civil status } \\
\text { Reference: Single }\end{array}$} \\
\hline Married & 0.387 & 1.402 \\
\hline Divorced & 0.495 & 1.641 \\
\hline Widow & $0.639^{*}$ & 1.878 \\
\hline \multicolumn{3}{|l|}{$\begin{array}{l}\text { Property status } \\
\text { Reference: Private school }\end{array}$} \\
\hline Public school & $-0.080^{\mathrm{NS}}$ & 0.923 \\
\hline \multicolumn{3}{|l|}{$\begin{array}{l}\text { Areas } \\
\text { Reference: Peri urbane/rural areas }\end{array}$} \\
\hline Urbane areas & $0.065^{\mathrm{NS}}$ & 1.067 \\
\hline
\end{tabular}




$$
{ }^{\mathrm{NS}} \mathrm{p}>0.05 ;{ }^{*} \mathrm{p}<0.05 ; \quad{ }^{* *} \mathrm{p}<0.01
$$

Referring to the above results can be asserted:

\section{A.Gender}

The results of Table 2 indicate that female teachers in lower secondary schools are most satisfied with their job then mal teachers $(p<0.05)$. The chances for female teachers to be satisfied with their teaching work are estimated to be about 1.78 times higher than for male teachers. This result is similar to the results communicated by other authors [2], [3], [9], [10], [11], [16], [20], [23], [24].

A similar result was communicated by [4], while [21] emphasize that the job satisfaction among Albanian teachers in the pre-university system is not influenced by gender.

\section{B. Age}

Age is identified as a factor with statistically significant effect $(\mathrm{p}<0.05)$ on job satisfaction among Albanian teachers in lower secondary school. The difference in the level of job satisfaction between teachers 31-40 year old and teachers 2030 years old are statistically significantly $(\mathrm{p}<.05)$.

The chances for teachers 31-40 year old to be satisfied is estimated to be about 2.207 times higher than for teachers 20 30 years old. For teachers $>40$ years old the chances of being satisfied with the teaching work they are about 1.98 times greater than their colleagues 20-30 years old.

The same type of relationship between the teacher's age with his job satisfaction has been communicated by other authors [7], [17], [19]. According to them "...the older the teacher is, the greater the chances that he will be satisfied at work"

\section{Work experience}

The results given in Table no.2, 3 confirm the relationship between teaching experience and job satisfaction $(p<0.01)$. More years of teaching are positively associated with job satisfaction in among the Albanian teachers in lower secondary education schools. The increase of the teaching period has, as a consequence, the increase of work experience, the better adaptation of the teacher to the different situations in teaching process, their professional growth and the increase of the feeling their work as a mission. These are factors that increase the level of job satisfaction among teacher will long teaching period, which as a rule, has a greater value than young teachers and / or teachers with less years of work experience as teachers. The study confirms that teachers who have a long teaching period, have about 2.6 times more opportunities to be satisfied compared to the teacher who have work experience $<5$ years. Similar results have been communicated by other authors [7], [30].

\section{Civil status}

Civil status is identified as a factor with a statistically significant effect $(\mathrm{p}<0.05)$ on job satisfaction among teacher. Meanwhile, it is important to note that the significant difference in the level of job satisfaction is identified only when comparing single teachers with teachers that are widow $(p<0.05)$. No significant differences in the level of job satisfaction are identified between teachers who have other civil status.

In contrast to communications made by other authors [17], [24], [30] this result shows that the hypothesis according to which civil status is not a factor with an important effect on job satisfaction among Albanian teacher in lower secondary education schools is even more likely to be true.

\section{E. Property status and areas where the school is located}

The study does not support the hypothesis about the relationship between property status of the school, its location and the level of job satisfaction among the teachers. This is a result similar to the results communicated by [2], [4], [21], [24], [29].

\section{CONCLUSION}

Between job satisfaction among the teachers in lower secondary schools in Albania and their demographic characteristics was identified a significant relationship. Female teachers declare more satisfied as male teachers. The teachers`age and work experiences are positively associated with job satisfaction. Civil status of teachers is a determinant with a small influence on job satisfaction.

The social-economic factors, property status of school (public or private) and residential area where the school is located (urban or peri-urban/rural), both have no significant influence on job satisfaction among the Albanian teachers in lower secondary schools.

\section{REFERENCES}

[1] Acker, S.. Chapter 3: Gender and teachers' work. Review of Research in Education, , 21(1), 99- 162, 1995. https://journals.sagepub.com/doi/abs/10.3102/0091732X021001099

[2] Ali, M.A., Tanveer-uz-Zaman, Tabassum, F., Iqbal, Z. A Study of Job Satisfaction of Secondary School Teachers. Journal of Education and Practice. 2011, Vol 2, No 1, 2011.

https://pdfs.semanticscholar.org/138b/63ea868ddc7de1fb061b803e1ec c58f2ab80.pdf

[3] Azhar, M., Nudrat, S., Asdaque,M.M.,Nawaz, A., Haider, N. A.Job Satisfaction of Secondary School Teachers: A Comparative Analysis of Gender, Urban and Rural Schools. Asian Social Science., Vol. 7, No. 8; August 2011

https://www.researchgate.net/publication/266466447_Job Satisfaction of Secondary School Teachers A Comparative Analysis of Gende Urban and Rural Schools

[4] Bezati, F. Faktorët që ndikojnë në kënaqësinë e punës së mësuesve të arsimit bazë në Shqipëri. Ph.D. dissertation, Dept. Phsicol. Faculty of Social Science, Tirana Public University, Albania, 2014 https://www.yumpu.com/xx/document/view/38241991/doktoraturafatmir-bezati-fakulteti-i-shkencave-sociale

[5] Brayfield, A. H., \& Rothe, H. F. An index of job satisfaction. Journal of Applied Psychology, 35(5), 307-311. 1951 https://doi.org/10.1037/h0055617

[6] Chirchir, R. Demographic Factors and Job Satisfaction: A Case of Teachers in Public Primary Schools in Bomet County, Kenya. Journal of Education and Practice. 2016, Vol.7, No.13, 2016.

https://files.eric.ed.gov/fulltext/EJ1102798.pdf

[7] Christina Ong Sook Beng, Siah Poh Chua, Tan Swee Mee. Demographic factors and job satisfaction of Malaysian chinese independent school teachers. 2020

http://apjee.usm.my/APJEE 35 _ 1 2020/apjee35012020 8.pdf

[8] Demirta, Z. (2010). Teachers' job satisfaction levels

https://www.researchgate.net/publication/251713327 Teachers' job satisf action levels

[9] Dhakal, S. A study of job satisfaction among primary school teachers in relation to their demographic variables. A International Journal of Education. Vol.4, No.2, July 2014, pp 46 - 57. 2014. https://www.academia.edu/31929269/A study of job satisfaction am ong primary school teachers in relation to their_demographic_vari ables

[10] Dhull.K., Jain, M. A study of attitude towards teaching profession in relation to job satisfaction among secondary school teachers. International Education \& Research Journal [IERJ]. Volume: 3. Issue:1 January, 2017. http://ierj.in/journal/index.php/ierj/article/view/645 
[11] Ghazi, S.R., Maringe, F. Age, gender and job satisfaction among elementary school head teachers in Pakistan. Education Knowledge and Economy 5(1-2):17-27, March 2011.

https://www.researchgate.net/publication/254271673_Age_gender_and_jo b satisfaction among elementary school head teachers in Pakistan

[12] Gosnell, S. Determinants of Career Satisfaction Among Federal Employees. Paper presented in Seminar on Public Policy Georgia Institute of Technology. Atlanta, Georgia, U.S.A. 2000

http://www.sciepub.com/reference/208362

[13] Johnson, J. L., \& Repta, R. Sex and gender. In J. L. Oliffe \& L. Greaves (Eds.), Designing and conducting gender, sex, and health research (pp. 17-37). Thousand Oaks, CA: Sage Publications. 2011

https://cjnr.archive.mcgill.ca/article/download/2359/2353

[14] Katoch. O.R. Job satisfaction among college teachers: A study on government colleges in Jammu (J\&K). Asian Journal of Research in Social Sciences and Humanities. Vol.2 Issue 4, April 2012. https://www.academia.edu/1798489/

[15] Kotherrja, O. Motivimi dhe performanca në punë (mësuesit e institucionit shkollor). Ph.D. dissertation, Dept. Phsicol. Faculty of Social Science, Tirana Public University, Albania. 2015

http://www.doktoratura.unitir.edu.al/wp-content/uploads/2017/01/OrtencaKotherja-doktorature-2015.pdf

[16] Kumar, M. S., Balasubraman, P.A Study on the Job Satisfaction of Primary School Teachers in Purasaiwakkam Area, Chennai. International Journal of Engineering and Management Research Volume- 9, Issue-4 (August 2019).

Available at: SSRN: https://ssrn.com/abstract=3479599

[17] Lalagka, S. Job satisfaction among Greek secondary teachers and the role of school. Journal of Contemporary Education. Theory \& Research, Vol. 1, No. 1, pp. 23-32. 2017

https://www.jcetr.gr/volliss1/1-1-4.pdf

[18] Ngimbudzi, F.W. (2009) Job satisfaction among secondary school teachers in Tanzania: The Case of Njombe District. Master's Thesis in Education.https://jyx.jyu.fi/bitstream/handle/123456789/25482/1/URN \%3ANBN\%3Afi\%3Ajyu-201010152985.pdf

[19] Perie, M., Bake, D. P. Job Satisfaction Among America's Teachers: Effects of Workplace Conditions, Background Characteristics, and Teacher Compensation. Statistical Analysis Report, 1997.

https://nces.ed.gov/pubs97/97471.pdf

[20] Poppleton, P., \& Riseborough, G. A profession in transition: Educational policy and secondary school teaching in England in the 1980s. Comparative Education, 1990, 26(2-3), 211-226.

https://www.jstor.org/stable/3099151

[21] Rapti, E.,Karaj, Th. The relationship between job satisfaction, demographic and school characteristics among basic education teachers in Albania. Problems of education in the $21^{\text {st }}$ century Volume 45, 2012

.http://www.scientiasocialis.lt/pec/files/pdf/vol45/73-80. Rapti Vol.45.pdf

[22] Sims, S. Essays on the recruitment and retention of teachers Ph.D. dissertation. University College London. 2018.

https://discovery.ucl.ac.uk/id/eprint/10053430/

[23] Singh, N., A Study of Job Satisfaction of Secondary School Teachers in NCR, India. International Journal of Trends in Business Administration. Volume1 issue 6, June 2012.

http://shodhganga.inflibnet.ac.in/jspui/bitstream/10603/173873/18/18publ ications.pdf

[24] Sultana A., Sarker, N.I., Prodhan, Sh. Job Satisfaction of Public and Private Primary School Teachers of Bogra District in Bangladesh. Journal of Sociology and Anthropology. 2017, Vol. 1 No. 1, 41-46.

http://pubs.sciepub.com/jsa/1/1/6/index.html

[25] Tasnim, Sh. (2006) Job Satisfaction among Female Teachers: A study on primary schools in Bangladesh.

$\underline{\text { http://hdl.handle.net/1956/1474 }}$
[26] Tirana, J. Impakti i stilit të drejtimit në nivelin e motivacionit dhe kënaqësisë së mësuesve në shkollë. Ph.D. dissertation, Dept. Phsicol. Faculty of Social Science, Tirana Public University, Albania, 2018

http://www.doktoratura.unitir.edu.al/2018/07/impakti-i-stilit-te-drejtimitte-drejtimit-ne-nivelin-e-motivacionit-dhe-kenaqesise-se-mesuesvene-shkolle/

[27] Toropova, A., Myrberg, E., Johansson, S. Teacher job satisfaction: the importance of school working conditions and teacher characteristics. Educational Review. 2020

https://doi.org/10.1080/00131911.2019.1705247

[28] Weiner, G. The nation strikes back: Recent influences on teacher education in Europe. Hitotsubashi Journal of Social Studies, 200638 (1), 79-88.

https://www.researchgate.net/publication/30780774_The nation_strikes back recent influences on teacher education in Europe

[29] Zembylas, M., \& Papanastasiou, E. Sources of Teacher Job Satisfaction and Dissatisfaction in Cyprus. Compare: A Journal of Comparative and International Education, 2006, 36, 229-247.

http://dx.doi.org/10.1080/03057920600741289

[30] Yucel, I., Bektas, C. Job Satisfaction, Organizational Commitment and Demographic Characteristics among Teachers in Turkey: Younger Is Better? Procedia-Social and Behavioral Sciences, 2012, 46, 15981608 .

https:/www.sciencedirect.com/science/article/pii/S1877042812014759/p df?md5=544382e891c3e691c97e47ac7e6d4982\&pid=1-s2.0S1877042812014759-main.pdf

[31] Zhilla, E. Motivacioni dhe nevojat e punonjësve akademikë në universitetet publike në Shqipëri. Ph.D. dissertation, Dept. Phsicol. Faculty of Social Science, Tirana Public University, Albania, 2014

http://www.doktoratura.unitir.edu.al/wpcontent/uploads/2014/12/Doktoratura-Eralda-Zhilla-Fakulteti-i$\underline{\text { Shkencave-Sociale-Departamenti-iy-Psikologji-Pedagogjise.pdf }}$

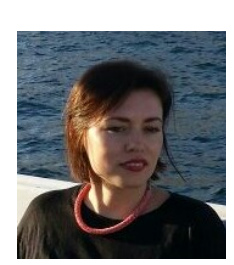

Enida Kume Prof.Asoc. Dr.

Enida Kume completed her university studies, Bachelor in "Social Work" and Master of Science in "Organization and Programming of Social Policies" at the University of Turin, Italy 20032008. He completed his postgraduate and doctoral studies at the Faculty of Social Sciences, University of Tirana, in the period 2010-2014.

In 2016 he was awarded the academic title Prof. Assoc.

In the period 2009-2019 she worked as a specialist in the Ministry of Education, Youth and Sports. Currently is a full-time academic staff at the Faculty of Education, "Aleksandër Moisiu" University of Durrës, Albania. She is the author of 13 scientific articles published in scientific journals and participant in 20 international scientific conferences. She is the author of a monography. 